\title{
Muhasebe Meslek Mensuplarının Karşılaştıkları Sorunlar Ve Beklentiler
}

Oğuzhan AYDEMIR*

\section{ÖZET}

Bu çalışma ile öncelikle muhasebe meslek mensuplarının sorunları ve çözüme yönelik beklentileri araştırılmaktadır. Bu bağlamda, muhasebe meslek mensuplarına yönelik web ortamında anket hazırlanmış ve uygulanmıştır. Elde edilen 428 adet anket değerlemeye alınmış ve SPSS kullanılarak analiz edilmiştir. Elde edilen sonuçlara göre "iş yükünün ağır olması", "bazı meslek mensuplarının çok ucuza defter tutması", "mükelleflerin ücretlerini ödememeleri veya düzensiz ödemeleri", "mesleki yeterlilik ve sorumluluklara karşın muhasebe meslek mensuplarının kazancının düşük olması" sırasıyla en önemli sorunlar olarak belirtilmiştir. Bununla birlikte, ankete katılanların yaklaşık \%80'i muhasebe meslek mensubu sayısının gereğinden fazla olduğunu düşünmektedir. Mükelleflerden beklentiler açısından ise "mükellefin ticari faaliyetlerini belgelendirmesi, düzenli belge tutması ve yanıltıcı belge kullanmaması" ve "mükellefin sorumluluklarının bilincinde olmasl" en önemli beklentilerdir. Katılımcıların çoğunluğu mesleğin özel yaşantılarını etkilediğini ve \%66,67’lik bir kesimde meslekten dolayı bir sağlık sorunu ile karşı karşıya kaldıklarını belirtmişlerdir.

Anahtar Kelimeler: Muhasebecilik Mesleği, Muhasebecilerin Sorunları, SMMM .

JEL Sinıflandırması: M40, M41.

\section{The Problems of Professionals in the Accountancy and Their Expectations}

\section{ABSTRACT}

In this study, primarily, the problems of professionals in the accountancy and expectations of them for solutions are investigated. In this regard, a questionnaire towards accountants was prepared and applied in the website. 428 questionnaires were obtained and analyzed by SPSS. According to findings, "intensive workload", "very cheap bookkeeping by some professionals", "irregular or no payment by taxpayers", "despite professional competence and responsibilities, low earnings of accountants" were stated as main problems, respectively. However, about $\% 80$ of the respondents thought that the number of accountants were redundant. In terms of expectations of accountants from taxpayers, "the certification of commercial activities by taxpayers, holding regular documents and not to use misleading documents" and "be aware of taxpayers in terms of their responsibilities" were the most primary expectations. Most of the respondents stated that their professions affected their private life and \%66,67 of respondents faced with a health problem because of their professions.

Keywords: Accountancy Profession, Problems of Accountants, CPA.

Jel Classification: M40, M41.

\footnotetext{
* Doç. Dr. Oğuzhan Aydemir, Namık Kemal Üniversitesi, İktisadi ve İdari Bilimler Fakültesi, aydemir69@gmail.com
} 


\section{GíRiş}

Muhasebe mesleği, ekonominin gelişmesi ve şirket yapılarının daha karmaşık hale gelmesi, mevzuatta yaşanan hızlı değişimler, meslek mensubu sayısında yaşanan hızlı artış ve neticesinde ücret ile ilgili ortaya çıkan haksız rekabet, mükelleflerin beklentilerindeki artış gibi nedenler dolayısıyla gittikçe daha stresli ve yorucu bir meslek haline gelmiştir. Günümüzde muhasebe meslek mensuplarının yaptıkları işler işletme kayıtlarının tutulması ve gerekli verilerin ilgili kişilere raporlanmasının ötesine geçmiş ve mükelleflerin çoğu sorunlarına çözüm bulma durumunda olan danışmanlık hizmeti haline gelmiştir. Bununla birlikte, aldıkları ücretlerde aynı doğrultuda bir artış olmaması meslek mensuplarının sıklıkla şikâyet ettikleri konu haline gelmiştir.

Muhasebe mesleği 1989 yılında yürürlüğe giren 3568 Sayılı Serbest Muhasebecilik, Serbest Muhasebeci Mali Müşavirlik ve Yeminli Mali Müşavirlik kanunu ile yasal bir konuma kavuşturulmuş ve muhasebecilik ve malî müşavirlik mesleğinin konusu kanunda açıkça belirtilmiştir. Buna göre, mesleğin çalışma konusu gerçek ve tüzel kişilere ait teşebbüs ve işletmelerin;

- "Genel kabul görmüş muhasebe prensipleri ve ilgili mevzuat hükümleri gereğince, defterlerini tutmak, bilanço, kâr-zarar tablosu ve beyannameleri ile diğer belgelerini düzenlemek ve benzeri işleri yapmak.

- Muhasebe sistemlerini kurmak, geliştirmek, işletmecilik, muhasebe, finans, malî mevzuat ve bunların uygulamaları ile ilgili işlerini düzenlemek veya bu konularda müşavirlik yapmak.

- Yukarldaki bentte yazıll konularda, belgelerine dayanılarak, inceleme, tahlil, denetim yapmak, mali tablo ve beyannamelerle ilgili konularda yazılı görüs vermek, rapor ve benzerlerini düzenlemek, tahkim, bilirkişilik ve benzeri işleri yapmak" olarak belirtilmiştir. $\mathrm{Bu}$ işleri bir işyerine bağlı olmaksızın yapanlara da serbest muhasebeci malî müşavir denmiştir (Resmi Gazete,13-06-1989 tarih ve 20194 Sayılı RG).

Küreselleşme ile birlikte işletmelerin yaptıkları işlemler daha karmaşık bir hale gelmiştir. İşletmeler ulusal sınırlar dışında da yatırımlar yapmaya, mal alıp satmaya ve şubeler açmaya başlamışlardır. Bu bağlamda, işletmelerin ve üçüncü kişilerin gereksinim duydukları bilgilerde de bir artış olmaya başlamıştır. Yurt dışı işlemlerinin değişik döviz cinslerinden olması ve kur hareketlerinin etkisi, vergi mevzuatındaki değişimler vb. konular meslek mensubunun kendisini devamlı olarak geliştirmesini gerekli kılmıştır.

$\mathrm{Bu}$ çalışma ile öncelikle muhasebe meslek mensuplarının sorunları ve beklentilerine yönelik literatür taraması yapılmış, daha sonra Türkiye genelinde yapılan anket uygulaması ile bu sorunlar ve beklentiler araştırılmıştır. 


\section{LITERATÜR TARAMASI}

Muhasebe meslek mensuplarının sorunlarına yönelik yapılmış araştırmalar olmasına rağmen zaman içerisinde bu sorunlarda değişimin yaşanabileceği bir gerçektir. Bu bağlamda bu bölümde bu konuda yapılmış araştırmalar ve sonuçlarına yer verilmekte ve zaman içerisindeki değişimler ortaya konmaktadır.

Arıkan (2006) muhasebe meslek mensuplarının sorumluklarını yerine getirirken aile ve özel yaşantılarından fedakarlıklar yaptıklarını belirtmiştir. Meslek mensubunun zamana karşı çalıştığını ve ağır iş yükü içerisinde olduğunu, yapılacak düzenlemeler ile bu yükün azaltılabileceğini belirtmiştir. Örneğin, geçici vergi dönemlerinde son 3 aya ait Beyanname alınmaması gerektiğini belirtmiştir. Bununla birlikte, meslek mensuplarının elde ettikleri gayri safi hasılattan "Mesleki Yıpranma" payı ile belirli bir kesiminin yıllık beyannamelerinden indirilmesi gerektiğini belirtmiştir.

Kalaycı ve Tekşen (2006) yaptıkları çalışma ile Isparta ilinde muhasebecilik mesleğini serbest olarak yapan meslek mensuplarına yönelik 52 adet anket gerçekleştirmiş ve muhasebecilik mesleğinde karşılaşılan sorunları araştırmışlardır. Araştırma bulgularına göre, meslek mensupları mevzuatta çok sık değişim olduğunu ve yaşanan değişimi takip etmekte zorlandıklarını, mesleğe yeni girenlerin ucuza defter tuttuklarını, iş yükünün çok fazla olmasına karşın maddi karşılığının yetersiz olduğunu, mükelleflerden istedikleri belgelerin zamanında alınamadığını vb. yaşanan problemler olarak belirtmişlerdir.

Işık, Özen ve Kabasoluk (2006) Denizli ilinde faaliyet gösteren yaklaşık 450 muhasebe meslek mensubuna yönelik yaptıkları anket uygulaması sonucu mükelleflerle yaşanan finansal zorlukların, mesleğin cazibesini yitirmesinin, meslek mensubu sayısının fazla olmasının, bürokratik işlemlerin, mevzuatın sık değişmesinin, ağır iş yükünün meslek mensupları açısından mesleğin en zorlu kısımları olduğu ortaya konmuştur. Mükelleflerden beklentiler açısından ise ücretlerin zamanında ödenmesi ve muhasebe mesleğine ve muhasebecilere karşı saygılı olunması ve karşılıklı güvene dayalı ilişki ön plana çıkmıştır.

Alagöz ve Ceran (2007) tarafindan Konya SMMM Odasına kayıtlı 354 meslek mensubuna yönelik yapılan anket uygulaması sonucuna göre meslek mensuplarının karşılaştıkları sorunlar arasında ilk üç sırayı kamu kurumlarında yaşanan sorunlar, mükellefler ile yaşanan sorunlar ve mevzuatla ilgili yaşanan sorunlar oluşturmaktadır. Mükelleflerle ilgili sorunlarda ise ücret kaynaklı sorunlar ilk sırayı almaktadır. Bunu bilgi ve belge akışından kaynaklanan sorunlar izlemektedir. Kamu kurumları ile yaşanan sorunlarda ise süre uzatmalarının son güne bırakılması, aşırı bürokratik işlemler, devamlı yapılan düzenlemeler neticesinde yaşanan iş yükü artışları vb. gösterilmektedir.

Özulucan, Bengü ve Özdemir (2010) yapmış oldukları anket çalışması ile Türkiye'de muhasebe meslek mensuplarının sorunlarını ve meslek odalarından beklentilerini araştırmışlardır. Elde edilen sonuçlara göre, SM ve SMMM'ler ücretlerin yetersiz olduğunu, mükelleflerin muhasebeyi önemsiz gördüklerini, ücret tahsilatında problemlerin yaşandığını 
vb. belirtmişlerdir. Yapılan çalışmada çoğunlukla muhasebe meslek mensuplarının sorunları ve bu sorunların demografik özellikleri ile ilişkileri irdelenmiştir.

Gökgöz ve Zeytin (2012) meslek mensuplarının karşılaştıkları sorunları belirlemek amacıyla Bilecik ve Yalova illerinde faaliyet gösteren 127 meslek mensubuna yönelik bir anket uygulaması gerçekleştirmişlerdir. Ankete katılanların \%26'sı serbest muhasebeci ve \%74'ü SMMM'dir. Araştırma sonucu meslek mensuplarının sorunları içerisinde iş yükünün çok fazla olmasının ilk sırada olduğunu göstermiştir. Diğer sorunlar sırasıyla alınan ücretlerin yetersizliği, devlet dairelerinde bürokratik işlemlerin fazlalı̆̆ mükelleflerden zamanında alınamaması, mükelleflerin evraklarını zamanında teslim etmemeleri, meslek mensuplarının özel hayatlarına zaman ayıramamaları vb. olarak sıralanmıştır. Meslek mensuplarının mükelleflerden beklentilerinde de ilk sırayı muhasebe ücretlerinin zamanında ödenmesi almıştır.

Tuğay ve Tekşen (2014) Burdur ilinde bağımsız olarak çalışan muhasebe meslek mensuplarına yönelik anket uygulamıştır. Elde edilen bulgulara göre, muhasebe meslek mensuplarının sorunları olarak muhasebeciden az vergi ödetmesinin istenmesi, çok ssk mevzuat değişikliklerinin olması, bazı meslek mensuplarının düşük ücret karşıllı̆ında defter tutması, yoğun iş yükü, ücretlerin tahsilinde yaşanan problemler vb. tespit edilmiştir. Mükelleflerden beklentiler açısından ise mükelleflerin belgeleri zamanında teslim etmeleri, vergi ödemelerini mükelleflerin kendilerinin yapması ve sahte belge düzenlememeleri ön plana çıkmıştır.

\section{ARAŞTIRMANIN AMACI}

$\mathrm{Bu}$ çalışma ile muhasebe meslek mensuplarının çalışma hayatında mükellefler, mevzuattaki değişimler, bürokratik işlemler vb. açıdan karşılaştıkları sorunlar belirlenmeye çalışılmıştır. Ayrıca, meslek mensuplarının mesleğin geleceğine ilişkin görüşleri ve sorunların çözümüne yönelik beklentilerinin ortaya konması amaçlanmaktadır.

\section{ARAŞTIRMANIN EVRENİ VE ÖRNEKLEMİ}

Araştırmanın evreni, Türkiye'de faaliyet gösteren muhasebe meslek mensuplarıdır. TÜRMOB verilerine göre 25-04-2015 tarihi itibari ile Türkiye'de toplam 10.503 SM, 82.427 SMMM ve 4.563 YMM olmak üzere 97.493 meslek mensubu bulunmaktadır. Bunların 72.320'si erkek, 25.173'ü bayandır. Eğitim durumuna bakıldığında ise 1519 kişi ilköğretim, 12888 kişi meslek lisesi, 4354 kişi önlisans, 74030 kişi lisans, 4250 kişi yüksek lisans ve 452 kişi doktora eğitimine sahiptir (http://www.turmob.org.tr/TurmobWeb/Istatistikler.aspx). Muhasebe meslek mensuplarına ulaşmada basit tesadüfi örnekleme seçim yöntemi uygulanmış ve bir hafta içerisinde 428 adet geri dönüşüm sağlanmıştır. Bu örneklem sayısı $\% 95$ güven aralığında evreni temsil edecek büyüklüktedir. 


\section{ARAŞTIRMANIN YÖNTEMI}

Çalışmada, Türkiye'de faaliyet gösteren meslek mensuplarına yönelik anket uygulanmıştır. Anket sorularının hazırlanmasında Işık, Özen ve Kabasoluk (2006) ve Gökgöz ve Zeytin (2012)'nin çalışmalarından faydalanılmıştır. Anket soruları iki ve çok seçenekli kapalı uçlu sorular ile 5'li likert ölçeğine göre hazırlanmış toplam 68 adet sorudan oluşmaktadır. Muhasebe meslek mensuplarına ulaşmanın zorluğundan dolayı anket web ortamında yayınlanmış ve ulaşılabilen meslek mensuplarının web ortamında anketi doldurmaları istenmiştir. Anket sonuçları SPSS 17 paket programı kullanılarak değerlendirilmiştir.

\section{ARAŞTIRMA BULGULARI}

Bu çalıșmada Olasılık Tutum Ölçeğinin güvenilirlik analizi yapılmıș olup Cronbach değeri 0,835 olarak belirlenmiştir. Bu sonuç ölçeğin yüksek derecede güvenilir bir ölçek olduğunu göstermektedir (Özdamar, 1997).

Anket çalışması sonucu demografik özellikler, mesleğe giriş ve sınavlar, meslek mensuplarının karşılaştıkları sorunlar, meslek mensuplarının iş memnuniyeti, mesleğin saygınlığının ve itibarının artırılmasına yönelik yapılması gerekenler, mükelleflerden beklentiler, mesleğin özel yaşama etkisi vb. konularda elde edilen sonuçlar takip eden bölümde tablolar halinde verilmiş ve özetlenmiştir.

Tablo 1: Ankete Katılanların Demografik Özellikleri

\begin{tabular}{|c|c|c|c|}
\hline & & FREKANS & YÜZDE \\
\hline \multirow{2}{*}{ CINSIYET } & Kadın & 57 & 13,34 \\
\hline & Erkek & 370 & 86,66 \\
\hline \multirow[t]{5}{*}{ YAŞ } & $20-30$ & 19 & 4,45 \\
\hline & $31-40$ & 121 & 28,34 \\
\hline & $41-50$ & 170 & 39,81 \\
\hline & $51-60$ & 87 & 20,37 \\
\hline & 60 ve üzeri & 30 & 7,03 \\
\hline \multirow[t]{2}{*}{ MEDENİ DURUM } & Evli & 364 & 86,26 \\
\hline & Bekar & 58 & 13,74 \\
\hline \multirow[t]{6}{*}{ AYLIK GELİR } & 2000 TL ve alt1 & 41 & 9,76 \\
\hline & $2001 \mathrm{TL}-4000 \mathrm{TL}$ & 159 & 37,86 \\
\hline & $4001 \mathrm{TL}-6000 \mathrm{TL}$ & 116 & 27,62 \\
\hline & $6001 \mathrm{TL}-8000 \mathrm{TL}$ & 47 & 11,19 \\
\hline & $8001 \mathrm{TL}-10000 \mathrm{TL}$ & 31 & 7,38 \\
\hline & 10001 TL ve üzeri & 26 & 6,19 \\
\hline \multirow[t]{6}{*}{ EĞİTíM DÜZEYİ } & İlköğretim & - & - \\
\hline & Lise & 23 & 5,45 \\
\hline & Ön Lisans & 9 & 2,13 \\
\hline & Lisans & 339 & 80,33 \\
\hline & Yüksek Lisans & 48 & 11,37 \\
\hline & Doktora & 3 & 0,71 \\
\hline \multirow[t]{2}{*}{ MESLEKİ DENEYİM SÜRESI } & $1 \mathrm{y} 1 \mathrm{l}-10 \mathrm{y} 1 \mathrm{l}$ & 70 & 16,75 \\
\hline & 11 yll -20 yll & 160 & 38,28 \\
\hline
\end{tabular}




\begin{tabular}{|c|c|c|c|}
\hline & $21 \mathrm{y} 1 \mathrm{l}-30 \mathrm{y} 1 \mathrm{l}$ & 120 & 28,71 \\
\hline & 31 y1l ve Üzeri & 68 & 16,27 \\
\hline \multirow[t]{5}{*}{ MESLEKİ UNVAN } & SM & 18 & 4,25 \\
\hline & SMMM & 245 & 57,78 \\
\hline & SMMM+ Bağımsız Denetçi & 158 & 37,26 \\
\hline & YMM & 0 & 0 \\
\hline & YMM + Bağımsız Denetçi & 3 & 0,71 \\
\hline \multirow[t]{2}{*}{ ÇALIŞMA ŞEKLI } & Bağımlı & 97 & 23,15 \\
\hline & Bağımsız & 322 & 76,85 \\
\hline \multirow{3}{*}{$\begin{array}{l}\text { ÇALIŞMA } \quad \text { YERİ } \\
\text { ÇALIŞANLAR IÇiN) }\end{array}$} & Muhasebe Bürosu & 78 & 50,98 \\
\hline & Özel Kuruluş & 70 & 45,75 \\
\hline & Kamu Kurumu & 5 & 3,27 \\
\hline
\end{tabular}

Ankete katılanların demografik özellikleri Tablo 1'de gösterilmektedir. Buna göre, araştırmaya katılanların yaklaşık \%87'si erkektir. Katılımcıların çoğunluğu $(\% 39,81)$ 41-50 yaş arasında olup toplamda ise \%67,21'i 40 yaşın üzerindedir. Evli olanların oranı ise yaklaşık \%86'dır. Aylık gelirler dikkate alındığında ise en büyük dilim \%37,86 ile 2001 TL4000 TL arasındadır. Eğitim düzeyi açısından ise lisans mezunları \%80,33 ile çoğunluğu teşkil etmektedir. Mesleki deneyim süresi bakımından katılımcıların \%83,25'i 10 yılın üzerinde deneyime sahiptir. Bu durum katılımcıların anket sorularını cevaplandırmada yeterli deneyime sahip olduklarının ve meslek mensuplarının sorunlarını daha iyi analiz edebildiklerinin bir göstergesidir. Katılımcıların \%57,78'i SMMM, \%37,26's1 ise SMMM ve Bağımsız Denetçidir. Tabloya göre katılımcıların \%76,85'i bağımsız çalışmaktadır. Bağımlı çalışanların ise \%50,98'i muhasebe bürolarında, \%45,75'i özel kuruluşlarda ve \%3,27'si ise kamu kurumlarında çalışmaktadır.

Tablo 2: Mesleğe Giriş ve Sınavlar

\begin{tabular}{|l|l|l|l|}
\hline \multicolumn{2}{|l|}{} & FREKANS & YÜZDE \\
\hline Mesleğe Giriş Konusunda Görüş̧ & Mevcut Sistem İyi ve Yeterlidir & 135 & 31,69 \\
\cline { 2 - 4 } & Mesleğe Giriş Zorlaştırılmalıdır & 249 & 58,45 \\
\cline { 2 - 4 } & Mesleğe Giriş Kolaylaştırılmalıdır & 42 & 9,86 \\
\hline \multirow{2}{*}{$\begin{array}{l}\text { Mesleğe Giriş Konusunda Yeni Bir Yasal } \\
\text { Düzenlemeye Gereksinim var mı? }\end{array}$} & Evet & 325 & 77,01 \\
\cline { 2 - 4 } & Hayır & 97 & 22,99 \\
\hline $\begin{array}{l}\text { Mali müşavirlik sınavına giriş için aranan } \\
\text { ön koşullar size göre mesleğin prestiji } \\
\text { bakımından yeterli midir? }\end{array}$ & Ön Koşullar Zorlaştırılmalıdır & 237 & 56,03 \\
\cline { 2 - 4 } & Ön Koşullar Kolaylaştırılmalıdır & 39 & 9,22 \\
\cline { 2 - 4 } \begin{tabular}{l} 
SMMM olmak size göre tüm süreçler göz \\
\multirow{2}{*}{ Önüne alındığında nasıllar Yeterlidir }
\end{tabular} & Çok Zor & 147 & 34,75 \\
\cline { 2 - 4 } & Zor & 59 & 14,01 \\
\cline { 2 - 4 } & Normal & 167 & 39,67 \\
\cline { 2 - 4 } & Kolay & 148 & 35,15 \\
\cline { 2 - 4 } & Çok Kolay & 35 & 8,31 \\
\hline
\end{tabular}

Tablo 2'ye göre katılımcıların \%58,45'i mesleğe girişin zorlaştırılması gerektiğini ifade ederken sadece \%9,86'sı kolaylaştırılması gerektiğini belirtmektedirler. Mesleğe giriş konusunda ise yaklaşık \%77'lik bir kesime göre yeni bir yasal düzenlemeye ihtiyaç vardır. Mesleğin prestiji bakımından mali müşavirlik sınavına giriş için aranan önkoşulların zorlaştırılması gerektiğini belirtenler yaklaşık \%56'lık bir kesimi içermektedir. Tabloya göre 
katılımcıların sadece \%11,16'i SMMM olmanın kolay olduğunu vurgulamakta olup \%53,68'i ise süreci çok zor ve zor olarak ifade etmektedirler. Buna rağmen mesleğe girişin \%58,45'lik kesim tarafından zorlaştırılması gerektiğini belirtmesi çelişkili bir durum olarak görünmektedir.

Tablo 3: Meslek Mensuplarının Karşılaştıkları Sorunlar

\begin{tabular}{|c|c|c|}
\hline & $\begin{array}{l}\text { Aritmetik } \\
\text { Ortalama }\end{array}$ & $\begin{array}{l}\text { Standart } \\
\text { Sapma }\end{array}$ \\
\hline Mesleğin cazibesini yitirmesi & 3,60 & 1,410 \\
\hline Meslek mensubu sayısının gereğinden fazla olması & 3,97 & 1,257 \\
\hline $\begin{array}{l}\text { Vergi dairesi ve iş gereği gidilmesi gereken diğer devlet kurumlarında } \\
\text { bürokrasinin fazla olması }\end{array}$ & 4,24 & 1,079 \\
\hline Mevzuatın sık sık değişmesi ve takip edilememesi & 4,39 & 1,030 \\
\hline İş yükünün ağır olması & 4,59 & 0,920 \\
\hline Mükelleflerin işletme karını yüksek göstermek istemeleri & 2,49 & 1,363 \\
\hline Büro ortamının ve iş düzeninin sıkıcı olması & 3,04 & 1,309 \\
\hline $\begin{array}{lccccc}\begin{array}{l}\text { Mesleki yeterlilik ve sorumluluklara } \\
\text { mensuplarının kazancının düşük olması }\end{array} & \text { karşı } & \text { muhasebe } & \text { meslek } \\
\end{array}$ & 4,44 & 1,024 \\
\hline Mükellefler tarafından az vergi ödetilmesi yönünde taleplerin olmas1 & 3,97 & 1,275 \\
\hline Mükelleflerin hukuka aykırı iş yaptırmak istemeleri & 3,30 & 1,414 \\
\hline İş yükünden dolayı özel hayata zaman ayrılamaması & 4,32 & 1,084 \\
\hline Denetimlerin çok olması & 3,27 & 1,257 \\
\hline Meslekle ilgili teknolojik gelişmelere ayak uyduramamak & 2,87 & 1,348 \\
\hline $\begin{array}{l}\text { Vergi incelemelerinde mükelleflerin potansiyel suçlu gibi görülmesi ve } \\
\text { tehditkar tavırlar }\end{array}$ & 4,11 & 1,155 \\
\hline Tecrübeli muhasebe elemanının bulunamaması & 3,77 & 1,203 \\
\hline $\begin{array}{l}\text { Uluslararas1 Muhasebe } \\
\text { görünmektedir }\end{array}$ & 3,73 & 1,201 \\
\hline Mükelleflerin ücretlerini ödememeleri veya düzensiz ödemeleri & 4,47 & 0,976 \\
\hline Bazı meslek mensuplarının çok ucuza defter tutması & 4,56 & 0,986 \\
\hline Mükelleflere ulaşmak zordur. & 3,28 & 1,304 \\
\hline Defter tutmanın yanında mükelleflerin tüm işleriyle ilgilenilmesi & 4,05 & 1,209 \\
\hline Mükelleflerin belgelerini zamanında ulaştırmaması & 4,12 & 1,165 \\
\hline
\end{tabular}

NOT: 1 Kesinlikle Katılmıyorum, 2. Katılmıyorum, 3. Kararsızım, 4. Katılıyorum, 5. Kesinlikle Katılıyorum

Tablo 3'de meslek mensuplarının karşılaştıkları sorunlar araştırılmıştır. Tabloda son 5 satırda yer alan sorunlar sadece bağımsız çalışan meslek mensuplarına yönelik sorulmuş olup diğerleri tüm meslek mensuplarını ilgilendirmektedir. Elde edilen sonuçlara göre muhasebe meslek mensuplarının karşılaştıkları en büyük sorun sırasıyla "iş yükünün ağır olması”, "Bazı meslek mensuplarının çok ucuza defter tutması", "Mükelleflerin ücretlerini ödememeleri veya düzensiz ödemeleri”, "Mesleki yeterlilik ve sorumluluklara karşın muhasebe meslek mensuplarının kazancının düşük olması", "Mevzuatın sık sık değişmesi ve takip edilememesi" vb. olarak belirlenmiştir. İkinci ve üçüncü sırada yer alan "Bazı meslek mensuplarının çok ucuza defter tutması”, “Mükelleflerin ücretlerini ödememeleri veya düzensiz ödemeleri” sadece bağımsız meslek mensuplarını ilgilendiren sorunlardır.

Bununla birlikte "Meslekle ilgili teknolojik gelişmelere ayak uyduramamak", "mükelleflerin işletme karını yüksek göstermek istemeleri”, "Büro ortamının ve iş düzeninin 
sıkıcı olması", “denetimlerin çok olması”, “mükelleflere ulaşmanın zor olması”, "mesleğin cazibesini yitirmesi" vb. sırasıyla diğerlerine göre daha az öneme sahip sorunlar olarak belirtilmiştir.

Yapılan çalışma ile meslek mensuplarının memnuniyeti ölçülmüş ve elde edilen sonuçlar Tablo 4'de özetlenmiştir. Buna göre, katılımcıların \%55,53'ünün muhasebe meslek mensubu olmaktan memnun oldukları belirlenmiştir. Diğer yandan, önemli bir kesim $(\% 44,47)$ muhasebe meslek mensubu olmaktan memnun değildir. Muhasebe meslek mensubu olmaktan memnun olanların ise \%61,90’1 memnuniyetini mesleğin gelişime açık olmasına, \%32,47'si ise prestijli bir meslek olmasına bağlamışlardır. Kazancının iyi olmasından dolayı muhasebe mesleğinden memnun olanların oranı ise sadece $\% 5,63$ 'dür.

Tablo 4: Meslek Mensuplarının Memnuniyeti

\begin{tabular}{|c|c|c|c|}
\hline & & FREKANS & YÜZDE \\
\hline \multirow{2}{*}{$\begin{array}{l}\text { Muhasebe meslek mensubu olmaktan } \\
\text { memnun musunuz? }\end{array}$} & Evet Memnunum & 231 & 55,53 \\
\hline & Hayır Memnun Değilim & 185 & 44,47 \\
\hline \multirow{3}{*}{$\begin{array}{l}\text { Muhasebe meslek mensubu olmaktan } \\
\text { memnunsaniz en önemli nedeni } \\
\text { nedir? }\end{array}$} & Mesleğin Gelişime Açık Olması & 143 & 61,90 \\
\hline & Prestijli Bir Meslek Olması & 75 & 32,47 \\
\hline & Kazancının İyi Olması & 13 & 5,63 \\
\hline \multirow{4}{*}{$\begin{array}{l}\text { Muhasebe meslek mensubu olmaktan } \\
\text { memnun değilseniz en önemli nedeni } \\
\text { nedir? }\end{array}$} & Meslek Mensubu Sayısının Fazla Olması & 41 & 22,16 \\
\hline & Kazancının Düşük Olması & 48 & 25,94 \\
\hline & İş Tatmini Sağlayan Bir Meslek Olmaması & 46 & 24,86 \\
\hline & Prestijinin Az Olması & 50 & 27,04 \\
\hline \multirow{3}{*}{$\begin{array}{l}\text { Mesleğinizin monoton bir yapısı } \\
\text { olduğunu düşünüyor musunuz? }\end{array}$} & Evet & 245 & 59,61 \\
\hline & Hayır & 126 & 30,66 \\
\hline & Kararsızım & 40 & 9,73 \\
\hline \multirow{2}{*}{$\begin{array}{lcr}\text { Türkiye'de } & \begin{array}{c}\text { mesleğin } \\
\text { saygınlığının } \\
\text { olduğunu } \\
\text { musunuz? }\end{array} & \begin{array}{r}\text { gerekli } \\
\text { düşünüyor }\end{array}\end{array}$} & Evet, düşünüyorum & 28 & 6,75 \\
\hline & Hayır, Düşünmüyorum & 387 & 93,25 \\
\hline
\end{tabular}

Muhasebe meslek mensubu olmaktan memnun olmayanlar ise bunun nedenlerini sırasıyla prestijinin az olmasına $(\% 27,04)$, kazancının düşük olmasına $(\% 25,94)$, iş tatmini sağlayan bir meslek olmamasına $(\% 24,86)$ ve meslek mensubu sayısının fazla olmasına (\%22,16) bağlamışlardır. Ayrıca, katılımcıların \%59,61'i mesleğin monoton bir yapıya sahip olduğunu belirtmektedirler. Son olarak, ankete katılanların \%93,25'i ise Türkiye'de mesleğin gerekli saygınlığının olduğunu düşünmemektedirler (Tablo 4).

Tablo 5: Mesleğin İtibarı ve Saygınlığının Artırılması Bakımından Sizce Hangileri Yapılmalıdır?

\begin{tabular}{|l|l|l|}
\hline & $\begin{array}{l}\text { Aritmetik } \\
\text { Ortalama }\end{array}$ & $\begin{array}{l}\text { Standart } \\
\text { Sapma }\end{array}$ \\
\hline $\begin{array}{l}\text { Oda yönetimi sorumluluklarının bilincinde olmalı (seminer organizasyonu, } \\
\text { eğitimler, iletişim ağının etkin kullanımı, kamuoyu ile mesleğe dair } \\
\text { paylaşımlar) }\end{array}$ & 1,068 \\
\hline $\begin{array}{l}\text { Mesleğe giriş sınavları daha zor bir formata kavuşturulmalı, meslek mensubu } \\
\text { sayısının kontrollü artışı sağlanmalı }\end{array}$ & 4,10 & 1,196 \\
\hline Mesleğe girilmesi sonrasında meslek mensupları güncel gelişmeleri takip & 4,45 & 0,969 \\
\hline
\end{tabular}




\begin{tabular}{|l|l|l|}
\hline ederek, kendilerini geliştirmeli & & \\
\hline $\begin{array}{l}\text { Üniversite ile daha fazla işbirliği yapılarak mesleğin akademik ayağı } \\
\text { güçlendirilmeli }\end{array}$ & 4,41 & 1,027 \\
\hline Ücretler artırılmalı & 4,35 & 1,019 \\
\hline $\begin{array}{l}\text { Meslek mensuplarının sık sık karşılaştığı mükellefin vergi kaçırmasında aracı } \\
\text { olma ithamlarına karşılık mesleği tanıtan, anlatan program, afiş vb. kamuoyu ile } \\
\text { paylaşılmalı }\end{array}$ & 4,39 & 0,992 \\
\hline Denetimler artırılmalı & 3,88 & 1,240 \\
\hline
\end{tabular}

NOT: 1 Kesinlikle Katılmıyorum, 2. Katılmıyorum, 3. Kararsızım, 4. Katılıyorum, 5. Kesinlikle Katılıyorum

Tablo 5'de mesleğin itibarı ve saygınlığının artırılması bakımından nelerin yapılması gerektiği konusunda katılımcıların düşünceleri yer almaktadır. Buna göre, öncelikle mesleğe girilmesi sonrasında meslek mensuplarının güncel gelişmeleri takip ederek, kendilerini geliştirmesinin, üniversite ile daha fazla işbirliği yapılarak mesleğin akademik ayağının güçlendirilmesinin, meslek mensuplarının sık sık karşılaştı̆̆ mükellefin vergi kaçırmasında aracı olma ithamlarına karşılık mesleği tanıtan, anlatan program, afiş vb. kamuoyu ile paylaşılmasının, ücretlerin artırılmasının gerektiği vb. belirtilmektedir.

Tablo 6: Meslek Mensubu Sayısının Yeterliliği

\begin{tabular}{|l|l|l|l|}
\hline \multicolumn{2}{|c|}{$\begin{array}{l}\text { FREKANS } \\
\text { YüZDE }\end{array}$} \\
\hline $\begin{array}{l}\text { Bulunduğunuz ilde meslek mensubu } \\
\text { sayısı hakkında görüşünüz nedir? }\end{array}$ & $\begin{array}{l}\text { Meslek mensubu sayısı gereğinden } \\
\text { fazladır }\end{array}$ & 333 & 80,43 \\
\cline { 2 - 4 } & Meslek mensubu sayısı yeterlidir & 60 & 14,49 \\
\cline { 2 - 4 } & Meslek mensubu sayısı gereğinden azdır & 21 & 5,08 \\
\hline $\begin{array}{l}\text { Eğer bağımsız çalışıyorsanız } \\
\text { bulunduğunuz ilde yeni bir büro açan } \\
\text { meslek mensubu sizi en çok hangi } \\
\text { yönden kaygılandırmaktadır? }\end{array}$ & $\begin{array}{l}\text { Piyasayı Küçültmesi } \\
\text { yoü açmasıt politikası ile haksı rekabete }\end{array}$ & 242 & 3,09 \\
\cline { 2 - 4 } & Kaygım yok & 71 & 74,92 \\
\hline
\end{tabular}

Muhasebe meslek mensubu sayısının yeterliliğine yönelik ankete katılanların düşünceleri Tablo 6'da yer almaktadır. Tabloya göre ankete katılanların \%80,43'lik bir kesimi meslek mensubu sayısının gereğinden fazla olduğunu ifade etmektedirler. Bağımsız çalışanların \%74,92'si ise yeni büro açan meslek mensuplarının düşük ücret politikası uygulamalarının haksız rekabete yol açması nedeniyle kendilerini kaygılandırdığını belirtmektedirler. Kaygı duymayanların oranı sadece \%21.99 olarak tespit edilmiştir.

Bağımsız çalışan muhasebe meslek mensuplarının mükelleflerden beklentileri Tablo 7'de özetlenmektedir. Buna göre, “mükellefin ticari faaliyetlerini belgelendirmesi, düzenli belge tutması ve yanıltıcı belge kullanmaması", "mükellefin sorumluluklarının bilincinde olması", "mükelleflerin muhasebe mesleğine ve muhasebecilere karşı saygılı olmaları ve mükellefle karşılıklı güvene dayalı bir ilişki geliştirme" vb. sırasıyla en önemli beklentiler olarak ortaya çıkmaktadır. 
Tablo 7: Eğer Bağımsız Çalışıyorsanız Mükelleflerle Olan İlişkilerinizde Beklentileriniz Nelerdir?

\begin{tabular}{|c|c|c|}
\hline & $\begin{array}{l}\text { Aritmetik } \\
\text { Ortalama }\end{array}$ & $\begin{array}{l}\text { Standart } \\
\text { Sapma }\end{array}$ \\
\hline Muhasebe ücretlerini düzenli ödemeleri & 4,22 & 1,303 \\
\hline Belgeleri zamanında teslim etmeleri & 4,21 & 1,229 \\
\hline Vergi ödemelerini mükelleflerin kendilerinin zamanında yapmas1 & 4,27 & 1,149 \\
\hline $\begin{array}{l}\text { Mükellefin ticari faaliyetlerini belgelendirmesi, düzenli belge tutması ve } \\
\text { yanıltıcı belge kullanmaması }\end{array}$ & 4,46 & 1,028 \\
\hline $\begin{array}{l}\text { Mükelleflerin muhasebe mesleğine ve muhasebecilere karşı saygılı olmaları ve } \\
\text { mükellefle karşılıklı güvene dayalı bir ilişki geliştirme }\end{array}$ & 4,43 & 1,044 \\
\hline Mükellefin sorumluluklarının bilincinde olması & 4,44 & 1,125 \\
\hline Mükelleflerin meslek mensuplarını aldıkları ücretlere göre değerlendirmemeleri & 4,37 & 1,119 \\
\hline
\end{tabular}

NOT: 1 Kesinlikle Katılmıyorum, 2. Katılmıyorum, 3. Kararsızım, 4. Katılıyorum, 5. Kesinlikle Katılıyorum

Tablo7'de yer alan beklentilerin aritmetik ortalaması dikkate alındığında ortalamanın tüm ifadeler için katılıyorum ve kesinlikle katılıyorum arasında olduğu yani mükelleflerden beklentilerin yüksek olduğu görünmektedir.

Tablo 8: Kamu Kurumları ile İlişkiler ve Kamu Politikaları

\begin{tabular}{|c|c|c|c|}
\hline & & FREKANS & YÜZDE \\
\hline \multirow{3}{*}{$\begin{array}{l}\text { İşiniz dolayısıyla temasta bulunduğunuz kamu görevlilerinin olumsuz } \\
\text { tutumlarına maruz kalıyor musunuz? }\end{array}$} & Evet & 259 & 65,40 \\
\hline & Hayır & 96 & 24,24 \\
\hline & Kararsızım & 41 & 10,35 \\
\hline \multirow{2}{*}{$\begin{array}{l}\text { Ekonominin kayıt altına alınması hususunda Maliye Bakanlığı'nın } \\
\text { çalışmalarını yeterli buluyor musunuz? }\end{array}$} & Evet, yeterli & 58 & 14,72 \\
\hline & $\begin{array}{l}\text { Hayır, } \\
\text { yetersiz }\end{array}$ & 336 & 85,28 \\
\hline
\end{tabular}

Ankete katılanların \%65,40’1 işleri dolayısıyla temasta bulundukları kamu görevlilerinin olumsuz tutumlarına maruz kaldıklarını ve \%85,28'i ise ekonominin kayıt altına alınması hususunda Maliye Bakanlığının çalışmalarını yeterli bulmadıklarını belirtmişlerdir (Tablo 8).

Tablo 9: Maliye Bakanlığı'nın Meslek Mensuplarına Dair Hangi Çalışmalara Ağırlık Vermesini Önerirsiniz?

\begin{tabular}{|l|l|l|}
\hline & $\begin{array}{l}\text { Aritmetik } \\
\text { Ortalama }\end{array}$ & $\begin{array}{l}\text { Standart } \\
\text { Sapma }\end{array}$ \\
\hline Bürokrasinin azaltılması & 4,52 & 0,959 \\
\hline $\begin{array}{l}\text { İnternet ve televizyon gibi iletişim araçlarıyla mükelleflerin vergi süreçleri } \\
\text { ile ilgili bilgilendirilmesi }\end{array}$ & 4,43 & 0,948 \\
\hline Ekonominin kayıt altına alınması & 4,62 & 0,838 \\
\hline Denetimlerin artırılması & 3,99 & 1,157 \\
\hline $\begin{array}{l}\text { Vergi mevzuatında yapılacak değişikliklerde muhasebecilerin de görüşünün } \\
\text { alınması }\end{array}$ & 4,69 & 0,814 \\
\hline Vergi incelemelerinde denetçilerin önyargılı davranmaması & 4,53 & 0,979 \\
\hline Vergi sisteminin daha basit hale getirilmesi & 4,51 & 1,018 \\
\hline
\end{tabular}

NOT: 1 Kesinlikle Katılmıyorum, 2. Katılmıyorum, 3. Kararsızım, 4. Katılıyorum, 5. Kesinlikle Katılıyorum 
Muhasebe meslek mensuplarının Maliye Bakanlığından beklentileri önem sırasına göre "vergi mevzuatında yapılacak değişikliklerde muhasebecilerin de görüşünün alınması", "Ekonominin kayıt altına alınması", "vergi incelemelerinde denetçilerin önyargılı davranmaması", "Bürokrasinin azaltılması", "Vergi sisteminin daha basit hale getirilmesi” vb. şeklinde sıralanmaktadır (Tablo 9).

Tablo 10: Mesleğin Özel Hayata Etkisi

\begin{tabular}{|l|l|l|l|}
\hline \multicolumn{2}{|c|}{} & FREKANS & YÜZDE \\
\hline $\begin{array}{l}\text { Mesleğinizde karşılaştı̆̆ınız sorunlar ve yoğun iş yükü özel } \\
\text { yaşantınızı etkiliyor mu? }\end{array}$ & Evet, etkiliyor & 348 & 84,06 \\
\cline { 2 - 4 } & Hayır, etkilemiyor & 11 & 2,66 \\
\cline { 2 - 4 } & Kismen etkiliyor & 55 & 13,29 \\
\hline $\begin{array}{l}\text { Mesleğinizden kaynaklandığını düşündüğünüz bir sağlık } \\
\text { sorununuz bulunmakta mıdır? }\end{array}$ & Evet & 276 & 66,67 \\
\cline { 2 - 4 } & Hayır & 138 & 33,33 \\
\hline
\end{tabular}

Tablo 10'da muhasebe mesleğinin özel hayata olan etkisi ile ilgili bulgular yer almaktadır. Buna göre, katılımcıların \%84,06'sı meslekte karşılaştıkları sorunların ve yoğun iş yükünün özel yaşantılarını etkilediğini belirtmektedirler. Etkilemiyor diyenlerin oranı sadece \%2,66'dir. Bununla birlikte ankete katılanların \%66,67'sinin meslekten kaynaklandığını düşündükleri bir sağlık sorunu bulunmaktadır. $\mathrm{Bu}$ durum muhasebe mesleğinin ne kadar stresli ve yorucu bir meslek olduğunun da bir göstergesidir.

Son soruda katılımcıların eklemek istedikleri düşünceleri sorulmuş ve 239 katılımcıdan alınan cevaplar aşağıdaki şekilde özetlenmiştir. Burada muhasebe mesleğinin sorunları ve katılımcıların beklentileri ile ilgili en fazla tekrarlanan beyanları yer almaktadır. $\mathrm{Bu}$ nedenle katılımcıların beyanlarını sorunlar ve beklentiler olarak özetlemek daha doğru olacaktır.

\section{Sorunlar:}

1. Meslek mensupları ücretlerini zamanında alamamakta ve mükellefler için muhasebeci en son para verilecek insan olarak görünmektedir.

2.

Mesleki yeterliliği olmayan bazı kişilerin SMMM yapılması hem haksız rekabeti arttırmakta hem de meslekte kaliteyi düşürmektedir.

3. Teknolojik gelişme meslek mensuplarının iş yükünü artırmaktadır.

4. Meslek mensupları fazla ve gereksiz iş yükünden dolayı kendi mesleğini geliştirmek yönünde zaman ayıramamakta, mevzuatı gereği gibi takip edememektedir.

5. Sorunlar çoğu kez dile getirilmiş olmasına rağmen şimdiye kadar herhangi bir iyileştirme yapılmamıştır.

6. Mevzuat değişikliklerine meslek mensuplarının anında ayak uydurması ve uygulaması istenmektedir. Bu durum sağlık problemleri sorunlarını artırmaktadır.

7. Meslek mensupları kendi mesleklerinin dışında diğer Ticari faaliyet kolları ile iştigal ettiklerinden mesleklerine ve işlerine gerekli özeni göstermemektedirler.

8. Kalifiye ve sorumluluk bilincine sahip eleman bulmak zordur. 
9. Mükellefler mali yükümlülüklerini muhasebecinin sorumluluğu gibi görmekte, kendileri bu sorumluluğu hissetmemektedirler.

10. Bildirim cezaları çok yüksektir. Örneğin, elemanların yaptıkları Ba ve Bs bildirimlerinin kontrol edilmesine rağmen sehven yapılan ve devletin kaybına neden olmayacak hatalara karşın ödenen cezalar üst düzeydedir. Bu cezaların art niyete ve hataya göre indirime tabi tutulması gerekmektedir.

11. Üniversitelerde verilen teorik muhasebe bilgilerinin yetersiz olması ve uygulama ile tam olarak uyuşmaması sorun olarak karşımıza çıkmaktadır.

12. Vergi dairelerinde, SGK müdürlüklerinde meslek mensuplarına karşı önyargılı davranılmaktadır.

13. Devlet mali müşavirleri kendi çalışanları gibi görmekte ve devlet kurumlarının yapması gerekli işlerin bir kısmı meslek mensuplarından beklenmektedir.

14. Son dakikaya kadar beklenip beyanname verme süresinin en son dakika uzatılması baskı yaratmaktadır.

\section{Beklentiler:}

1. Ücretlerin bir şekilde garanti altına alınması gerekmektedir. Ödeme yapmayan mükellef kara listeye alınabilir ve incelemeye sevk edilebilir. Ücretler devlet kanalı ile alınabilir.

2. Muhasebe ücretlerinin beyannamelerin tahakkuklarına yansitılarak ay sonları maliye bakanlığınca meslek mensubunun hesabına ödenmesi sağlanabilir.

3. Ücret tespit ve tahsilinde otomasyona gidilmeli, ücretler senelik olarak kredi kartı gibi bir sistemle aylık taksitlerle alınmalı ve tahsilat sistemde göründükten sonra beyanname onaylanabilmelidir.

4. Beyan ve bildirimler basitleştirilmeli, lüzumsuz olanlar kaldırılmalıdır. Damga vergisine son verilmelidir.

5. Mesleğin uzun vadede hak edeceği saygınlık ve onura kavuşması umut edilmektedir.

6. Vergi mevzuatı sade, şeffaf ve adil olmalı ve konuyla ilgili düzenlemeler meslek mensuplarına sorulmalıdır. Ayrıca, mesleki alanda yapılan mevzuat değişikliklerinde meslek mensuplarının ve meslek kuruluşlarının mutlaka görüşünün alınıp ona göre işlem yapılması gerekmektedir.

7. Maliye'nin mükelleflere uyguladığı cezanın birinci muhatabı mali müşavirlerdir. Ceza tutarlarının hafifletilmesi muhasebecilerin stresini azaltacaktır.

8. Vergi beyanlarını meslek mensubu dışında kimsenin doldurmaması ve imzalamaması gerekmektedir.

9. Meslek mensuplarına tutacakları defter sayısı bakımından sınırlama getirilmesi ve müşteri kotasının gelmesi gerekmektedir.

10. Mesleğe giriş zorlaştırılmalıdır. Giriş sınavlarında uygulamaya yönelik sorular olmalidir. 
11. Muhasebe mesleği konusundan meslek mensubundan ziyade mükellef bilgilendirilmeli ve bilinçlenmesi sağlanmalıdır.

12. Meslek mensubu olma hakkının sadece üniversitelerin ilgili bölümlerine verilmesi gerekmektedir.

13. Mali tatilde verilmesi gereken beyannamelerin bir sonraki ayda verilmesi rahatlık sağlayacaktır.

\section{SONUÇ VE DEĞERLENDİRME}

Muhasebecilik mesleği ekonomik faaliyetlerin düzgün işlemesi, yatırımların artması, güven ortamının oluşması, kamu maliyesi vb. açıdan büyük önem arz etmektedir. Günümüzün karmaşık işletme yapıları, işletme faaliyetlerinin çeşitlenmesi, mevzuatta yaşanan hızlı değişim vb. nedenlerle muhasebecilik mesleği daha ağır iş yükü içerisinde faaliyetlerine devam etmektedir. Ayrıca, mükelleflerin muhasebecilik mesleğinden beklentileri artmakta ve karşılaştıkları her konuda kendilerinden çözüm bulması beklenmektedir.

$\mathrm{Bu}$ çalışma ile muhasebecilik mesleğinin karşılaştığ 1 sorunlar ve meslek mensuplarının beklentileri belirlenmeye çalışılmaktadır. Bu bağlamda, muhasebe meslek mensuplarına yönelik anket uygulanmış ve elde edilen 428 adet anket değerlemeye alınmıştır.

Elde edilen sonuçlara göre "iş yükünün ağır olması”, "bazı meslek mensuplarının çok ucuza defter tutması”, “mükelleflerin ücretlerini ödememeleri veya düzensiz ödemeleri”, "mesleki yeterlilik ve sorumluluklara karşın muhasebe meslek mensuplarının kazancının düşük olması" sırasıyla en önemli sorunlar olarak tespit edilmiştir.

Ankete katılanların yaklaşık \%80'i muhasebe meslek mensubu sayısının gereğinden fazla olduğunu düşünmektedirler. Mükelleflerden beklentiler açısından ise "mükellefin ticari faaliyetlerini belgelendirmesi, düzenli belge tutması ve yanıltıcı belge kullanmaması" ve "mükellefin sorumluluklarının bilincinde olması" sırasıyla en önemli beklentiler olarak belirlenmiştir. Katılımcıların çoğunluğu mesleğin özel yaşantılarını etkilediğini ve \%66,67'lik bir kesiminde meslekten dolayı bir sağlık sorunu ile karşı karşıya kaldıklarını belirtmişlerdir.

Anketin son sorusunda katılımcıların belirtmek istediği düşünceleri sorulmuş ve 239 kişi sorunlarını ve beklentilerini belirtmiştir. Buna göre, katılımcılar çoğunlukla ücretlerini tahsil etmedeki problemlerden, yoğun iş yükünden, mevzuattaki hızlı değişimlerden, sorumluluklarının çok fazla olmasından, meslek mensubu sayısının hızlı artmasından ve haksız rekabetten ve yeterli saygıyı görememekten vb. şikayet etmektedirler.

Beklentiler açısından ise, ücretlerinin tahsiline yönelik bir çözüm yolunun bulunmasını, beyan ve bildirimlerin basitleştirilmesini, mesleğin hak ettiği saygınlığa kavuşmasını, mesleki alanda yapılacak düzenlemelerde meslek mensuplarının ve meslek kuruluşlarının da görüşünün alınmasını, meslek mensuplarının tutacakları defter sayısına bir kota getirilmesini vb. talep etmektedirler. Sonuç olarak, bu sorunlar ve beklentilerin değerlendirilerek muhasebe mesleğinin hak ettiği konuma getirilmesi gerekmektedir. 


\section{KAYNAKLAR}

Alagöz, Ali - Ceran, Yunus (2007), “Muhasebe Meslek Mensuplarının Sorunları, Meslek Örgütünden Beklentileri ile Mesleki Vizyon Algılarını Belirlemeye Yönelik Bir Araştırma: Konya İli Uygulaması", Selçuk Üniversitesi İktisadi ve İdari Bilimler Fakültesi, Sosyal ve Ekonomik Araştırmalar Dergisi, Sayı 14, ss. 291-312.

Arıkan, Yahya (2006). "Muhasebe Meslek Mensuplarının Vergi Uygulamalarındaki Sorunlarına İlişkin Çözüm Önerilerimiz”, Mali Çözüm, Sayı: 75, ss. 13-19.

Gökgöz, Ahmet - Zeytin, Mustafa (2012), "Muhasebe Meslek Mensuplarının Mesleki Faaliyetlerinde Karşılaştıkları Sorunlar ve Beklentileri: Bilecik Ve Yalova İlleri Uygulaması", Süleyman Demirel Üniversitesi, İktisadi ve İdari Bilimler Fakültesi Dergisi, c. 17 , s. 1 , ss. 477-493.

http://www.turmob.org.tr/TurmobWeb/Istatistikler.aspx (25-04-2015)

Işık, Abdulkadir- Özen, Zafer - Kabasoluk, Orhan (2006), "Meslek Mensuplarının Sorunları ve Çözüm Önerileri”, Denizli SMMMO, Yayın no: 8, Denizli.

Kalaycı, Şeref - Tekşen, Ömer (2006), "Muhasebecilik Mesleğinde Karşılaşılan Sorunlar ve Çözüm Önerileri: Isparta İl Merkezi Uygulaması”, Muhasebe ve Finansman Dergisi, Sayı 31, ss. 90-101.

Özdamar, K. (1997), "Paket programlar ile İstatistiksel Veri Analizi-1”, Kaan Kitabevi, Eskişehir.

Özulucan, A-, Bengü, H. - Özdemir, F. S. (2010), "Muhasebe Meslek Mensuplarının Güncel Sorunları, Uygulamada Karşılaştıkları Yetersizlikler Ve Meslek Odalarından Beklentilerinin Unvanları Ve Mesleki Deneyim Süreleri Yönüyle İncelenmesi: Türkiye Genelinde Bir Araştırma”, Muhasebe ve Denetime Bakış, 31, ss. 41-64.

Resmi Gazete, 13-06-1989 tarih ve 20194 Sayll http://www.resmigazete.gov.tr/arsiv/20194.pdf

Tuğay, Osman - Tekşen, Ömer (2014), "Muhasebe Meslek Mensuplarının Sorunları: Burdur İlinde Bir Araştırma", Süleyman Demirel Üniversitesi, İ̈BF Dergisi, C. 19, s. 1, ss. 223-232. 